\title{
Geomechanical Characteristics And Failure Analysis of The Limestone Slope At Sahastradhara- Chamasari Road Dehradun Uttarakhand India
}

Nirlipta Priyadarshini Nayak

UPES: University of Petroleum and Energy Studies

Harinandan Kumar ( $\square$ harinandankumar88@gmail.com )

UPES: University of Petroleum and Energy Studies

Ashish Aggarwal

UPES: University of Petroleum and Energy Studies

Muralidhar Singh M.

MITS: Madanapalle Institute of Technology and Science

\section{Research Article}

Keywords: Geology of Study Area, Geotechnical Characterization, Slope Failure Analysis, Statistical Analysis, Factor of Safety (FOS)

Posted Date: September 13th, 2021

DOI: https://doi.org/10.21203/rs.3.rs-732835/v1

License: (c) (i) This work is licensed under a Creative Commons Attribution 4.0 International License. Read Full License 


\section{Abstract}

In this study, the rock slope failure analysis was carried out to predict the stability of the limestone rock in the Sahastradhara-Chamasari Road Dehradun Uttarakhand, India. The limestone rock samples were collected from the study area for testing purposes. The geomechanical parameters like compressive strength, axial strain, young's modulus, cohesive strength, angle of internal friction, etc., were experimentally determined to study their application in the simulation of slope failure analysis. A 2D model of the study area was developed using the field data for modelling and simulation purposes. Slope failure analysis was carried out using the Finite element method (FEM). Results indicated maximum compressive strength of the core sample as $85.14 \mathrm{MPa}$ while axial strain and elastic modulus were 0.02197 and $842.45 \mathrm{MPa}$, respectively. The cohesive strength and the angle of internal friction of the core sample were evaluated as $38.59 \mathrm{kPa}$ and 12.96 degree. The slope failure analysis was carried out to determine the factor of safety (FOS) of the slope at variable loading conditions. A decreasing trend of the FOS was observed with loading. The lesser value of FOS at higher loading conditions required the supporting system at the foot level of the slope for the slope stability in the study area.

\section{Introduction}

Slope failure is one of the most common hazards of the mountainous and hilly regions worldwide. The natural phenomena, as well as human interference, is the major contributor for the slope instability. For many years, the slope failure analysis is being carried out to control the slope's instability [1-3]. A frequent slope instability problem has been observed in the hilly area during the road and structural construction [4-5]. The stability of the slope is only possible by analyzing the highly influencing parameters during the road construction and structural work in the hilly area. The geomechanical properties of rock and slope geometry are the most critical parameters that cause slope failure. The geomechanical properties of rock include compressive strength, Poisson's ratio, cohesive strength, and angle of internal friction. The slope geometry consists of the angle of the slope, the height of the slope, the geology of the rock, boundary conditions, etc. [6-7]. The Mohr-Coulomb Failure Criteria (M-C Criteria) is one of the most acceptable methods for determining the factors responsible for rock slope failure and the factor of safety [8]. The slope stability is generally determined in terms of the factor of safety in the $\mathrm{M}-\mathrm{C}$ criteria. The material properties like Young's modulus, Poisson's ratio, cohesive strength, and angle of internal friction are the basic inputs for the determination of slope stability problems using the M-C criteria [9-10]. This criterion gives an outlook of the mode of failure and the post-failure analysis of the slope. Modelling and simulation using the finite element method (FEM) are popular approaches for slope failure analysis. The FEM method utilizes the equilibrium equation and strain compatibility for the determination of the slope failure. This method uses $\mathrm{M}-\mathrm{C}$ criteria to determine the mode of failure and the factor of safety of the slope [9-11]. M-C criteria were used to evaluate slope stability in the Handlebar Hill open-pit mine located at Mt. Isa, north Queensland, Australia [12]. The M-C criteria were used to determine shear strength parameters and the factor of safety of the slope in the study area [13]. 
The literature review summary confirmed that the application of the Finite element method (FEM) and utilization of the $\mathrm{M}-\mathrm{C}$ criteria is helpful for the slope failure analysis. This approach is suitable for determining factors affecting the slope failure and the aspect of safety of the slope. Therefore, in this paper, the slope failure analysis was carried out using the finite element method (FEM) and utilizing the $\mathrm{M}-\mathrm{C}$ criteria to solve the slope failure problem. The samples were collected from the study area for testing purposes. Experimental tests were carried out to determine geomechanical properties like compressive strength, elastic modulus, Poisson's ratio, cohesive strength, and angle of internal friction. Slope failure analysis was carried out to determine the FOS and variation of strain in the slope.

\section{Location Of Study Area}

The Sahastradhara (thousand fold spring) is one of Dehradun's most popular tourist places in the Uttarakhand state of India. The place is famous for the natural beauty in terms of the water drips from the limestone stalactites, sulfur springs, small mountains, caves, and terrace farming, etc. Most of the mountains in this area composed of limestone rock and steep-sloped. The presence of hollow cavities and fractures was observed in the Limestone of the study area. The Sahastradhara is connected with the nearby village Chamasari through the Sahastradhara-Chamasari Road. The mountain in this road is very steep, and hollow cavities and fractures have often been seen in the limestone rock of this area (The country-rock, i.e., Limestone is fractured and having numerous solution cavities). The stability of the slope is essential for safe transportation and construction work in this area. In such terrains, slope stability plays a very vital role in civil as well as transportation. Therefore, the rock samples Considering the same, samples were collected from the study area to determine the geomechanical properties and to carry out the slope failure analysis. Shastradhara has situated around $14 \mathrm{~km}$ from Dehradun, the state capital of Uttarakhand. Sahastradhara, the study area, comes under the Lesser Himalaya zone and contains economically viable minerals. The site is located at $30^{\circ} 24^{\prime} 18^{\prime \prime} \mathrm{N}$ latitude and $78^{\circ} 07^{\prime} 57^{\prime \prime} \mathrm{E}$ longitude and shown in Figs. 1 and 2.

The area is rich in carbonate formation. Krol belt is well exposed in the area with thinly bedded shale and is found with carbonate rocks with some gypsum pockets. The Krol Supergroup is otherwise known as Krol Nappe [14]. It is divided into two groups, including the outer Krol belt in the SW region with deposition

in the Shimla group and the inner Krol belt in the NE region with deposits of Mandhali Formation [15]. The Krol Group is characterized by mainly carbonate-evaporate succession. It is divided into three formations: The Mahi Formation characterized by calc-argillaceous, and the Jarashi Formation shows gypsum pockets in shale. The Kauriyala Formation consists of a sequence of carbonate with thin beds of shale. The lower member Krol C consists of black color limestone with lenticular pockets of gypsum. Gypsum formation happened due to the oxidative weathering of sulfides and black shales. This produces sulphuric acid, which further reacts with silicates and carbonate rocks to generate sulfate ions and combine with calcium in solution to form gypsum.

\section{Methodology}


The methodology to execute the research work is shown in Fig. 3.

\section{Sample Collection and Preparation}

The limestone blocks were collected from the study area (Fig. 4). Sampling locations were chosen at the points where freshly exposed limestone outcrops were present. The location points showed highly fractured limestone intercalated with Gypsum.

The limestone block was transported to the laboratory for testing purposes (Fig. 4). A total of thirty core samples was of NX size, and L/D ratio 2 to 2.5 were recovered from the limestone block for testing purpose (Fig. 5). The core samples were polished at both ends. The cores were prepared to determine geomechanical parameters such as ultimate compressive strength, triaxial compressive strength, axial strain, cohesive strength, and angle of internal friction as per the prescribed standards IS $9143-1979$ and IS 13047 - 1991, respectively (Fig. 6).

\section{Slope Failure modelling}

Slope failure analysis using numerical modelling is an essential method for evaluating the natural slope and rock mass stability during their movement. The slope stability analysis is critical to know the factors that initiate the natural slope or rock mass movement at variable conditions. The Limestone Slope of Sahastradhara-Chamasari Road Dehradun Uttarakhand, India, requires a slope stability analysis for safe transport throughout the year. In order to carry out the slope analysis, a 2D framework structure of the study area was modeled based on the field data. The slope failure analysis carried out using geomechanical properties of the sample obtained from the study area and utilizing the dedicated software suit. The slope of the study area was developed in a 2D framework structure for the analysis purpose, as shown in Fig. 7.

The analysis was carried out using the established Mohr-Coulomb Failure Criteria. The elastic modulus and Poisson's ratio of the material used in this analysis. The data of cohesive strength and angle of internal friction were collected from the experimentations. A discretized triangulated element of $2.5 \mathrm{~cm}$ length was used to meshing the structure (Fig. 8). A variable load from 100 to $2000 \mathrm{kN}$ was applied, as shown in Fig. 8.

\section{Experimentation}

The geomechanical properties like unconfined compressive strength, axial strain, triaxial strength, etc., were determined as per the standard IS 9143 - 1979 and IS 13047 - 1991, respectively. The compressive strength was determined using the compression-testing machine, as shown in Fig. 9. The compressive strength and axial strain was determined in the displacement mode at $0.5 \mathrm{~mm} /$ minutes. Triaxial strength was determined using the triaxial cell and the triaxial set up as shown in Fig. 10.

\section{Results And Discussions}


The geomechanical properties like compressive strength, axial strain, triaxial strength, cohesive strength, angle of internal friction, and elastic modulus of the sample obtained from the study area were determined for the slope failure analysis. The results obtained summarized in following section shown in following sub-sections.

\section{Compressive Strength}

The compressive strength of the core samples was determined as per the prescribed standard. The bulk density of core samples was determined as per the dimensions and weight of the core sample (Table 1). The compressive strength was determined in displacement mode at $0.5 \mathrm{~mm} /$ minute using the compressive testing apparatus. The core sample was placed in between the upper and lower platens of the compression testing setup. The change in length of the core samples was determined using the dial gauge. The load was determined using the proving ring. The reading of the dial gauge and the proving ring were used to determine the strain and load applied to the core sample. The core samples' compressive strength was obtained by dividing the cross-sectional area of core samples by that of load applied. The results of the compressive strength test are shown in Table 2. The maximum compressive strength of the core sample was $85.14 \mathrm{MPa}$. The corresponding axial strain was 0.02197 . After testing, the fracture profile of the core sample indicated a weak zone in the limestone because of the intercalated with Gypsum (Fig. 9c). The presence of the weak zone is responsible for structural discontinuities and rockfalls in the limestone slope.

Table 1

Dimension of core sample

\begin{tabular}{|lllll|}
\hline Specimen Id. & Length $(\mathrm{mm})$ & Diameter $(\mathrm{mm})$ & Weight $(\mathrm{g})$ & Density $\left(\mathrm{kg} / \mathrm{m}^{3}\right)$ \\
\hline S-C-1 & 100.12 & 41.3 & 352.2 & 2627.23 \\
\hline
\end{tabular}


Table 2

Compressive strength data of core sample

\begin{tabular}{|llll|}
\hline Displacement (mm) & Load $(\mathrm{N})$ & Stress $(\mathrm{MPa})$ & Strain \\
\hline 0.1 & 96110 & 71.78 & 0.00100 \\
\hline 0.2 & 97210 & 72.60 & 0.00200 \\
\hline 0.3 & 98760 & 73.76 & 0.00300 \\
\hline 0.4 & 99230 & 74.11 & 0.00400 \\
\hline 0.5 & 101010 & 75.44 & 0.00499 \\
\hline 0.6 & 102110 & 76.26 & 0.00599 \\
\hline 0.7 & 103210 & 77.08 & 0.00699 \\
\hline 0.8 & 104390 & 77.96 & 0.00799 \\
\hline 0.9 & 105110 & 78.50 & 0.00899 \\
\hline 1 & 106810 & 79.77 & 0.00999 \\
\hline 1.1 & 107190 & 80.05 & 0.01099 \\
\hline 1.2 & 108150 & 80.77 & 0.01199 \\
\hline 1.3 & 108670 & 81.16 & 0.01298 \\
\hline 1.4 & 109780 & 81.99 & 0.01398 \\
\hline 1.5 & 110320 & 82.39 & 0.01498 \\
\hline 1.6 & 110890 & 82.82 & 0.01598 \\
\hline 1.7 & 112230 & 83.82 & 0.01698 \\
\hline 1.8 & 112780 & 84.23 & 0.01798 \\
\hline 1.9 & 113000 & 84.39 & 0.01898 \\
\hline 2 & 113600 & 84.84 & 0.01998 \\
\hline 2.1 & 84.91 & 0.02097 \\
\hline 2.2 & 85.14 & 0.02197 \\
\hline
\end{tabular}

A stress-strain graph was obtained based on the experimental data (Fig. 11). The elastic modulus 842.45 $\mathrm{MPa}$ of the sample was determined based on the stress-strain diagram. A sharp increase in the compressive strength was obtained with the load application indicating the rock's good bearing capacity in the study area. A fracture was obtained in the gypsum lining showed the weak zone of the rock sample.

\section{Triaxial Strength}


The core sample was subjected to lateral and axial load using the triaxial cell and the triaxial setup. The results of the test are shown in Table 3 and Fig. 12. The cohesive strength of the sample was $38.59 \mathrm{kPa}$, and the angle of internal friction was 12.96 degree.

Table 3

Triaxial strength data of core sample

\section{Slope Failure Analysis}

Specimen Id. Confining Pressure (kPa) Axial Stress (kPa)

$\begin{array}{lll}\text { S-C-1 } & 0 & 84.94\end{array}$

$490 \quad 780$

$1192+1961$

The failure analysis was carried out using the established Mohr-Coulomb Failure Criteria. The elastic modulus and Poisson's ratio of the material used in this analysis were $842.45 \mathrm{MPa}$ and 0.25 , respectively. The cohesion and angle of internal friction was $38.59 \mathrm{kPa}$ and 12.96 degree. A variable load of $100 \mathrm{kN}$ to $2000 \mathrm{kN}$ was applied to the model to determine the factor of safety (FOS) and the elastic properties of the slope. The results are presented and discussed in the following subsections.

\section{Factor of Safety (FOS) of Slope}

The failure analysis was carried out using the established Mohr-Coulomb Failure Criteria. The elastic modulus and Poisson's ratio of the material used in this analysis were $842.45 \mathrm{MPa}$ and 0.25 , respectively. The cohesion and angle of internal friction was $38.59 \mathrm{kPa}$ and 12.96 degree. A variable load of $100 \mathrm{kN}$ to $2000 \mathrm{kN}$ was applied to the model to determine the factor of safety (FOS) and the strain developed in the slope. The factor of safety of the structure varied from 1.002 to 0.654 with an increase in load from 100 to $2000 \mathrm{kN}$ (Fig. 13). A correlation between the FOS and load was applied established using the least square regression method. The correlation indicated a decrease in FOS with load and a linear correlation coefficient of 0.95 obtained at variable loading conditions (Fig. 14). The developed strain in slope structure was determined at variable loading conditions from 100 to $2000 \mathrm{kN}$, as shown in Fig. 15. A curvature of strain was observed in the middle of the slope at $100 \mathrm{kN}$, but a shifting of strain towards the load point indicated the localized strain at the higher loading conditions. A decrease in FOS and localized strain at the load point exhibited the instability in the slope at higher loading conditions. The instability is due to the load exceed the cohesive strength and initiation of the fracture in limestone. As the limestone of the study area was highly weathered and intercalated with Gypsum, the initiation and propagation of fracture was easy and is one of the major factors for the reduced FOS at higher loading conditions. In general, The presence of the weak zone is responsible for structural discontinuities and rockfalls in the limestone slope. The FOS value was more than 1 in the case of $100 \mathrm{kN}$ while it was less than 1 in all other loading conditions. The lesser value of FOS requires the supporting system at the foot level of the slope for the stability of the slope on the study area. 


\section{Conclusions}

The paper discusses the geomechanical properties of the limestone rock samples obtained from the Sahastradhara-Chamasari Road Dehradun Uttarakhand, India. The study was carried out with a vision to evaluate terrain safety. The experimentally obtained geomechanical properties and field data were utilized to develop the 2D structure of the study area and simulate for the slope failure analysis. The following observations are concluded from this study:

- The limestone rock in the study area was highly fractured and intercalated with Gypsum.

- The unconfined compressive strength test indicated the maximum compressive strength of the core sample as $85.14 \mathrm{MPa}$.

- The axial strain and elastic modulus of the core sample were recorded as 0.02197 and $842.45 \mathrm{MPa}$.

- The triaxial testing results indicated the cohesive strength and the angle of internal friction as 38.59 $\mathrm{kPa}$ and 12.96 degree.

- A decrease in the factor of safety (FOS) of the slope was observed with the load. The reduction in FOS has attributed to the load exceed the cohesive strength and initiation of the fracture in limestone.

- As the limestone of the study area was highly weathered and intercalated with Gypsum, the initiation and propagation of fracture was easy and is one of the significant factors for the reduced FOS at higher loading conditions.

- The shifting of the strain values towards the point of load applied was observed in the slope failure analysis.

- In in-situ conditions, the terrain can sustain the maximum load of $100 \mathrm{kN}$. However, in the case of increased load, the supporting system at the foot level of the slope was highly recommended for the stability of the slope in the study area.

\section{Ethical Statement}

- All authors of this research paper have directly participated in the planning, execution, or analysis of this study

- The contents of this manuscript are not now under consideration for publication elsewhere

- The contents of this manuscript will not be copyrighted, submitted, or published elsewhere, while acceptance by the Journal is under consideration;

- There are no directly related manuscripts or abstracts, published or unpublished, by any authors of this paper.

- The authors declare that they have no competing interests.

\section{References}

1. Hudson JA, Harrison J. P (1997) Engineering rock mechanics. Pergamon, London 
2. Zhou JW, Xu WY, Yang XG, Shi C, Yang ZH (2010) The 28 October 1996 landslide and analysis of the stability of the current Huashiban slope at the Liangjiaren Hydropower Station, Southwest China. Eng Geol 114:45-56

3. Olkel JV, Huber J, Leopold M (2011) Significance of slope sediments layering on physical characteristics and interflow within the Critical Zone-examples from the Colorado Front Range, USA. Appl Geochem 26:143-145

4. Lee H, Baraza J (1999) Geotechnical characteristics and slope stability in the Gulf of Cadiz. Mar Geol 155:no. 1-2, "'”, , pp. 173-190

5. Anbazhagan S, Ramesh V, Saranaathan SE (2017) Cut slope stability assessment along ghat road section of Kolli hills. India Nat Hazards 86:1081-1104

6. Zhao LH, Cao JY, Tang GP (2014) Discussion on slope stability analysis with double strength reduction technique. Rock Soil Mechanics 35:2977-2984

7. Xue HB, Dang FN, Yin X, "Nonproportional correlative reduction finite element method for slope strength parameters", Mathematical Problems in Engineering, Vol. 2016, pp. 10, 2016

8. Zhao L, Yang F, Zhang Y, Dan H, Liu W (2015) Effects of shear strength reduction strategies on safety factor of homogeneous slope based on a general nonlinear failure criterion. Comput Geotech 63:215-228

9. Su K, Li Y, Cheng D (2016) Slope Stability Analysis Under Combined Failure Criteria. The Open Civil Engineering Journal 10:125-131

10. Dong S, Jiang Y, Yu X, "Analyses of the Impacts of Climate Change and Forest Fire on Cold Region Slopes Stability by Random Finite Element Method", Landslides, https://doi.org/10.1007/s10346021-01637-1, 2021

11. Yuan WH, Liu K, Zhang W, Dai B, Wang Y, “Dynamic modeling of large deformation slope failure using smoothed particle finite element method", Landslides, Vol. 17, pp. 1591-1603, 2020

12. Salmasi F, Pradhan B, Nourani B (2019) Prediction of the sliding type and critical factor of safety in homogeneous finite slopes. Applied Water Science 9:158

13. You G, Mandalawi MA, Soliman A, Dowling K, Dahlhaus P, "Finite Element Analysis of Rock Slope Stability Using Shear Strength Reduction Method", Soil Testing, Soil Stability and Ground Improvement, Vol. 2017, pp. 227-235, 2017

14. Biyani AK (2006) Dimensions of Himalayan Geology". Satish Serial Publication House, Delhi, p 330 15. Bhargava ON, “Reinterpretation of Krol belt”, Himalayan Geology, Vol. 2, pp. 47-81, 197

\section{Figures}




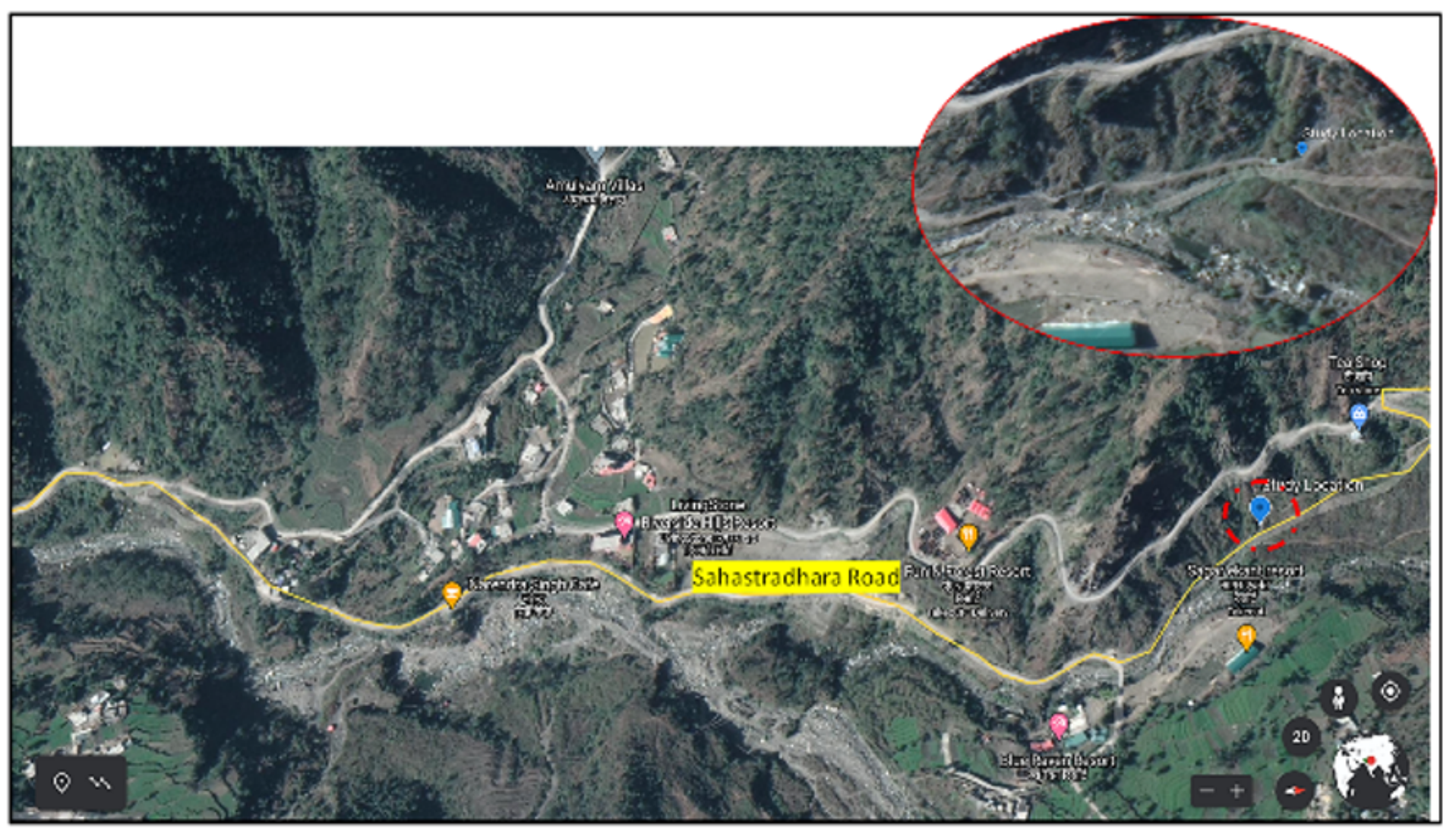

\section{Figure 1}

\section{Location map of Study Area}

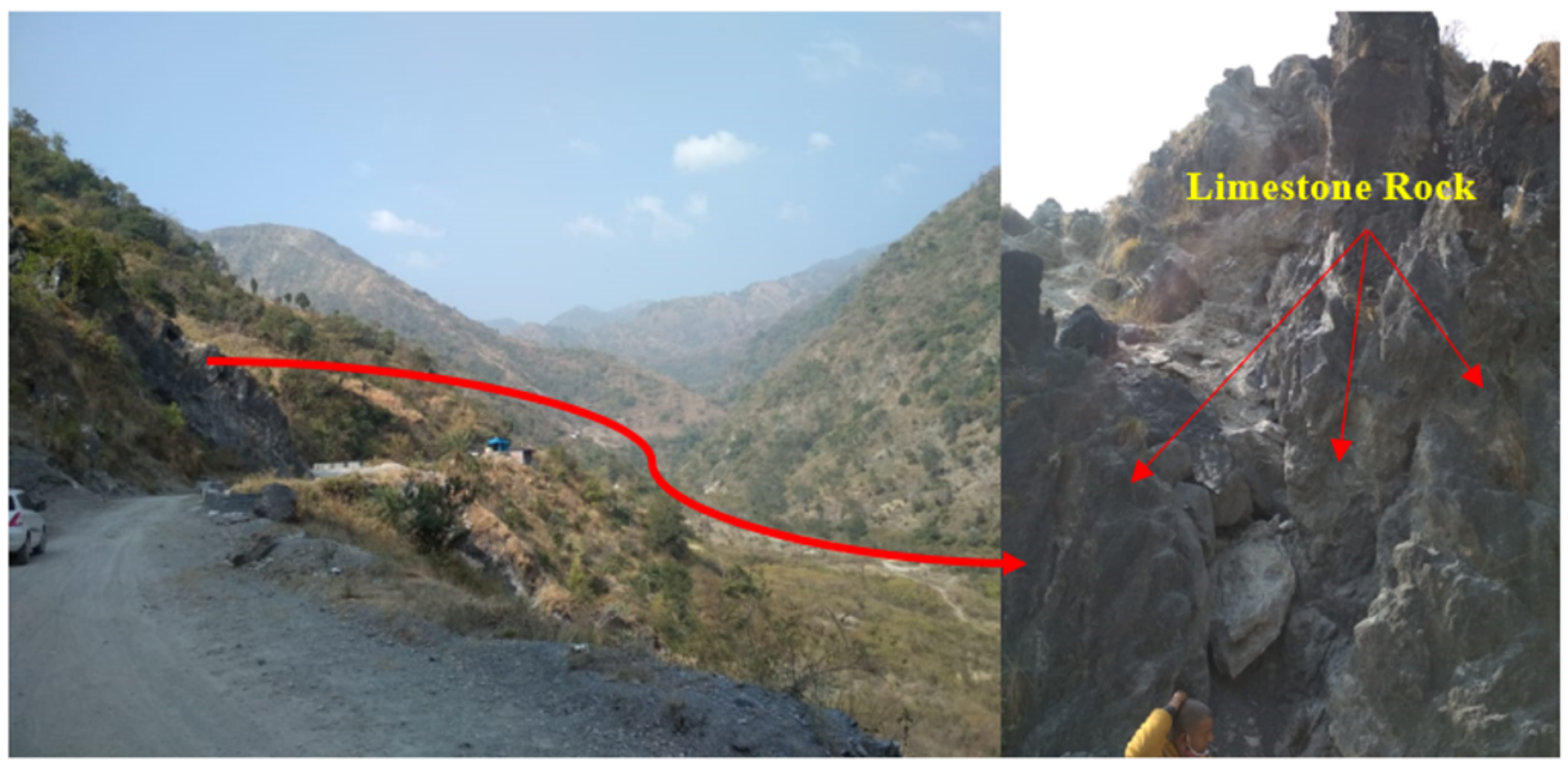

Figure 2 


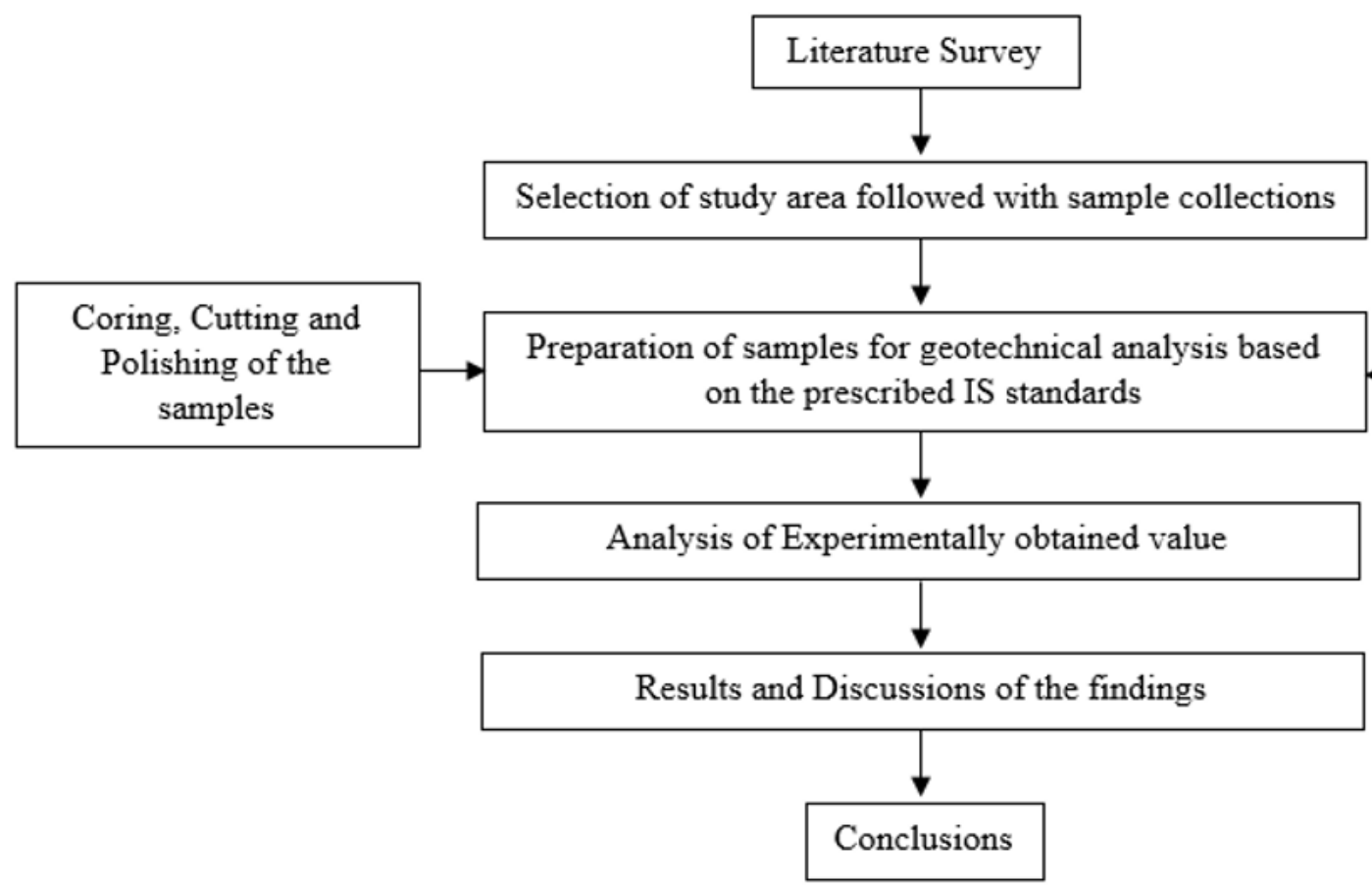

\section{Figure 3}

Methodology of the Research Work 


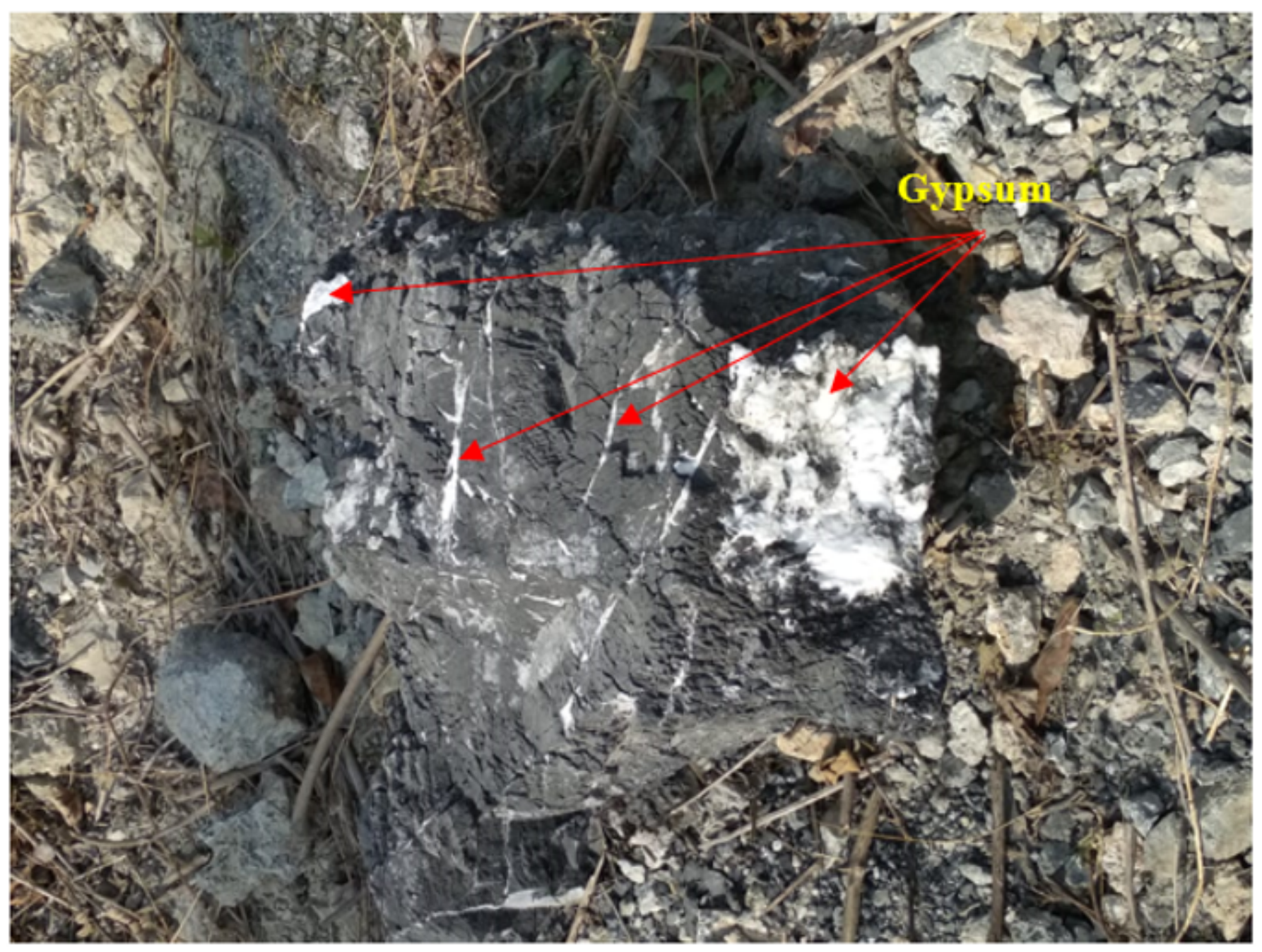

\section{Figure 4}

Collected Limestone sample intercalated with Gypsum 


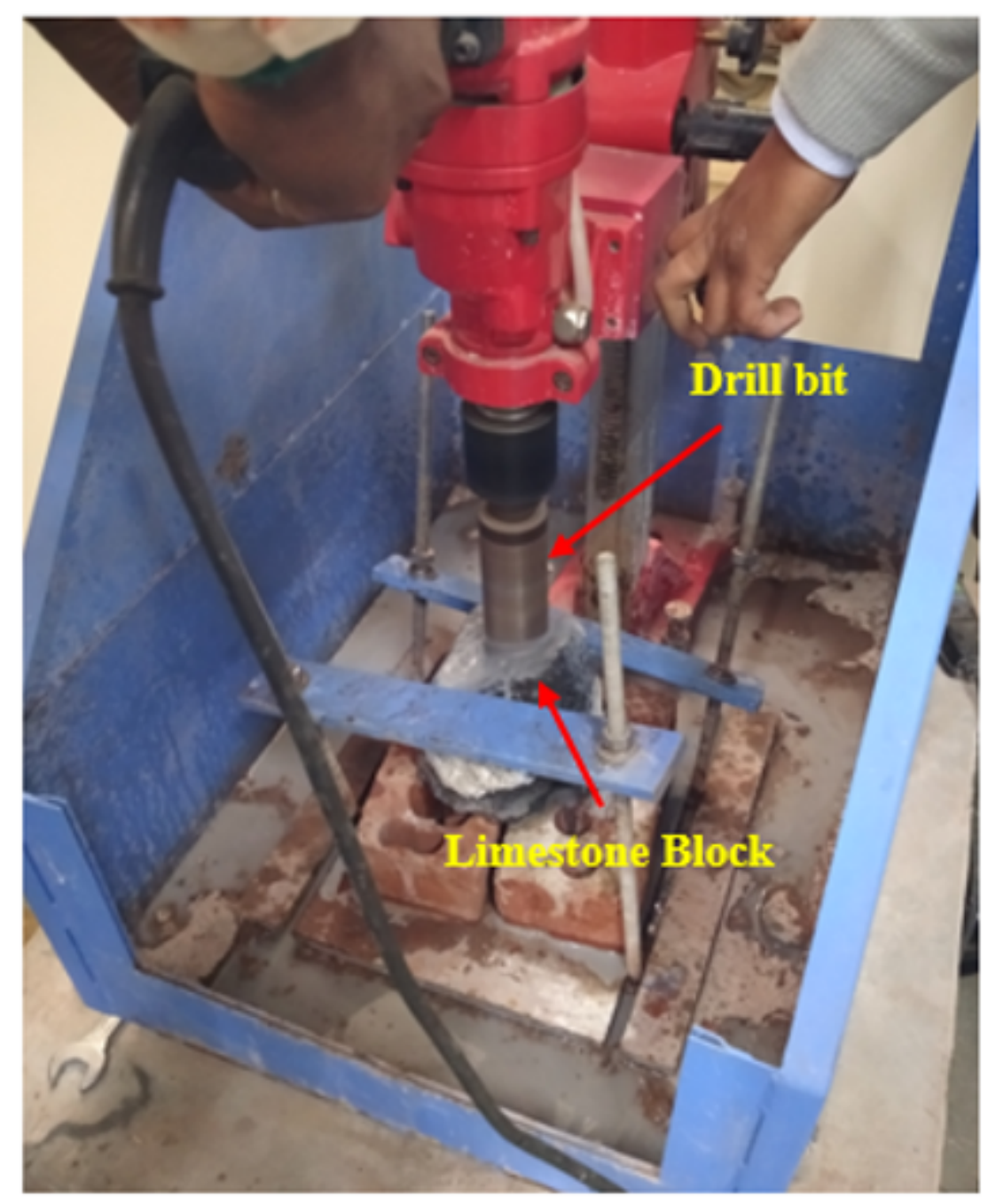

Figure 5

Coring of the Limestone Block 


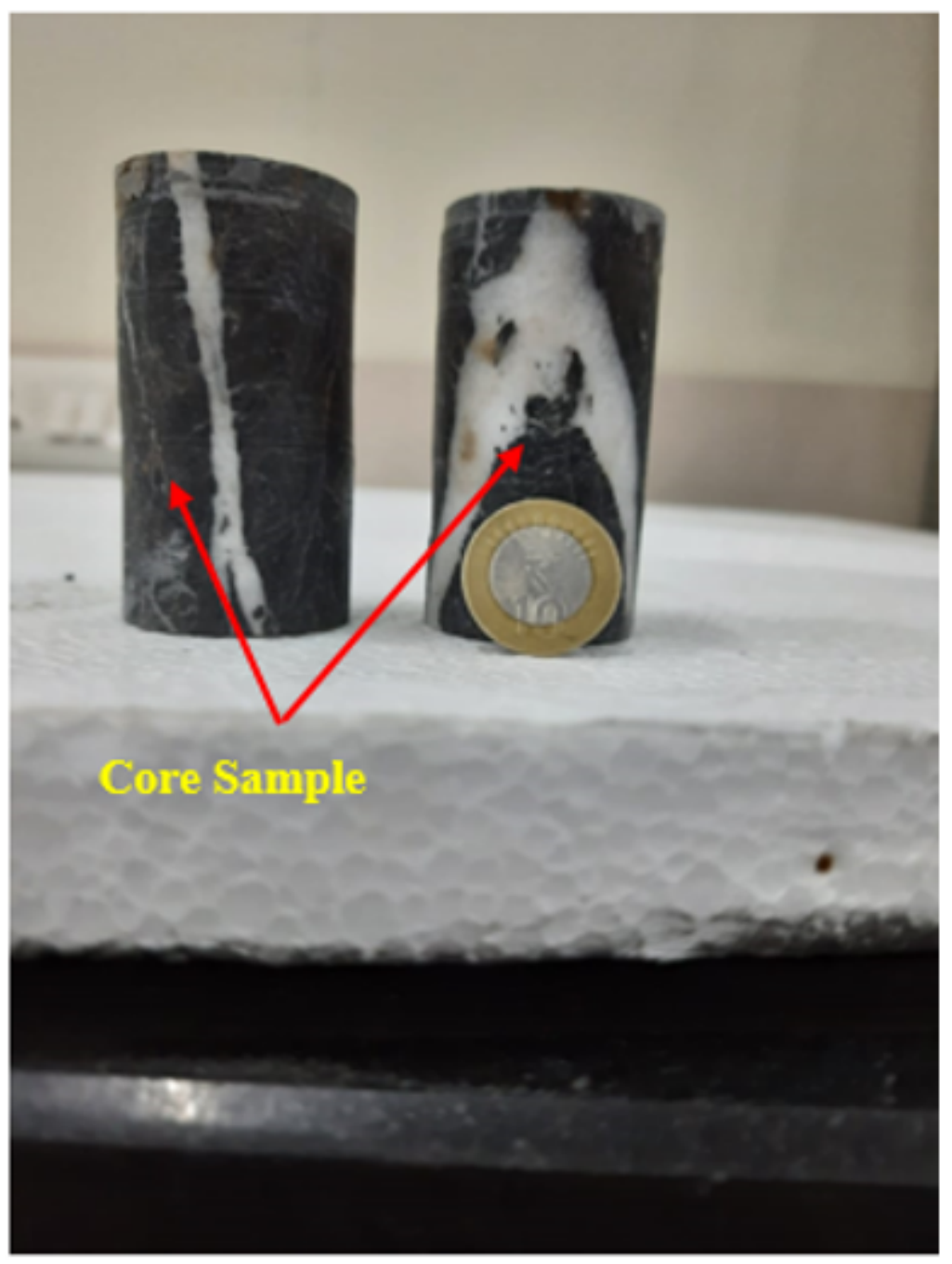

Figure 6

Core sample after coring and polishing 


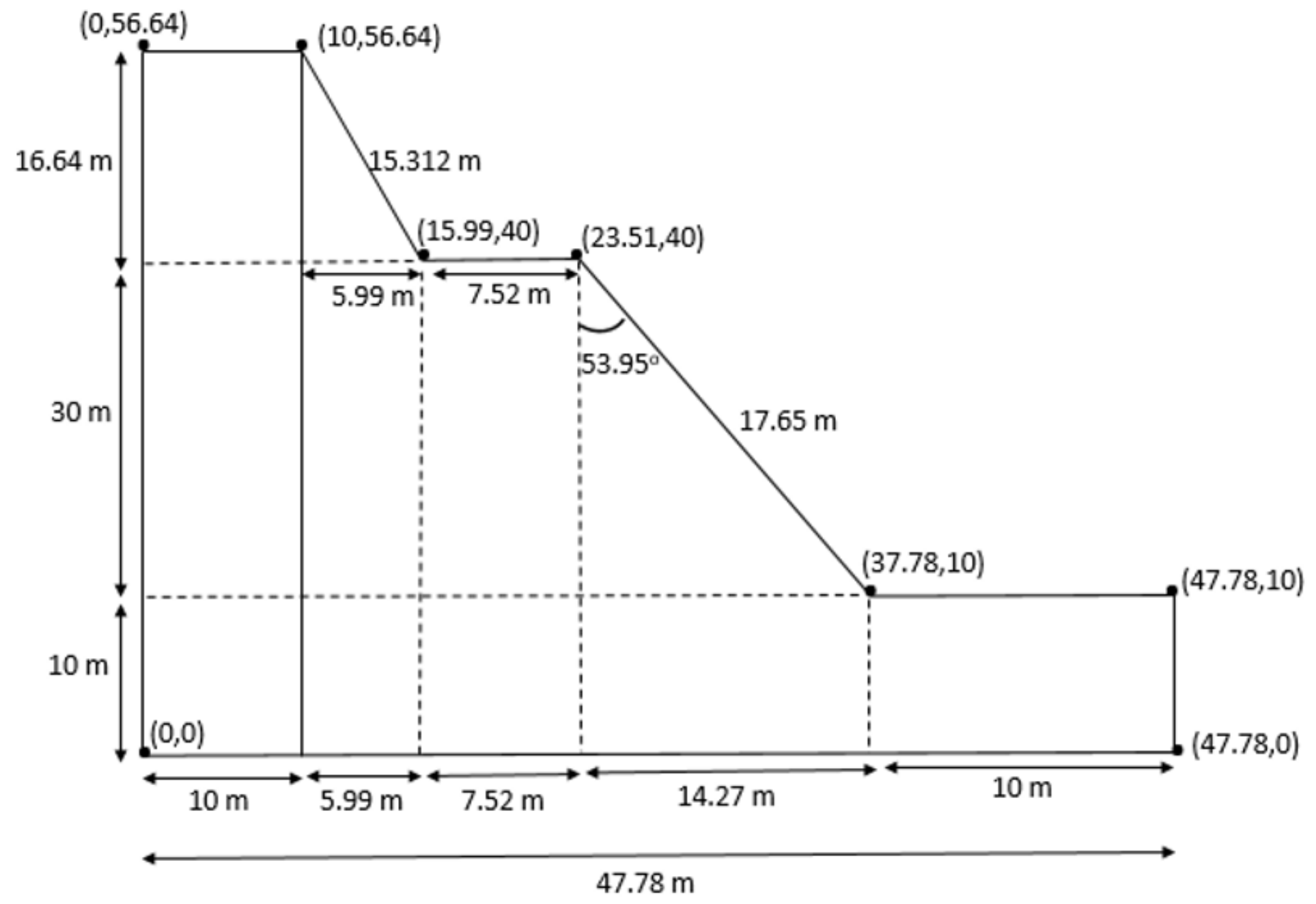

Figure 7

2D framework structure of the slope of the study area (not in scale) 


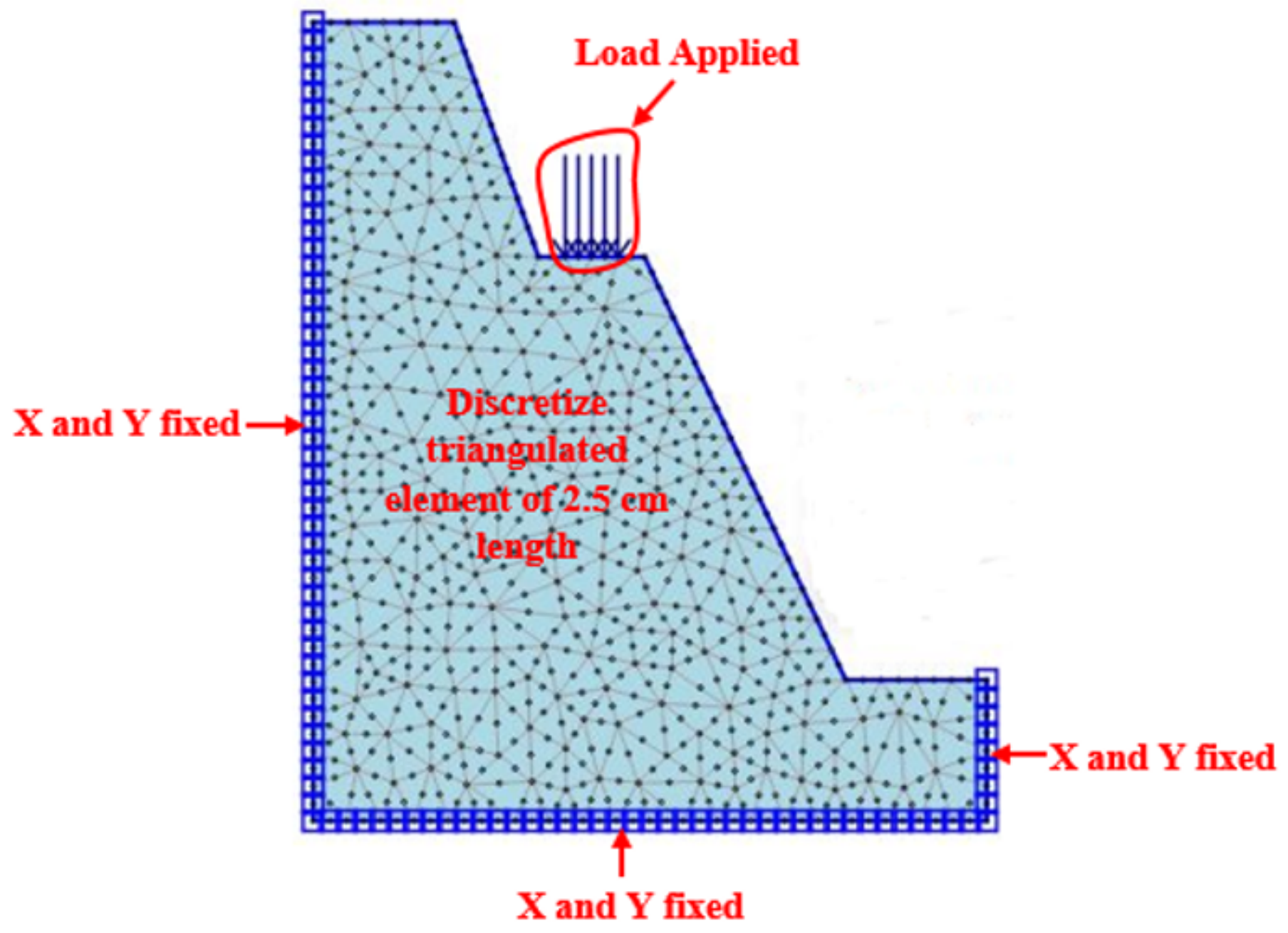

Figure 8

Meshed framework structure with boundary conditions and load applied
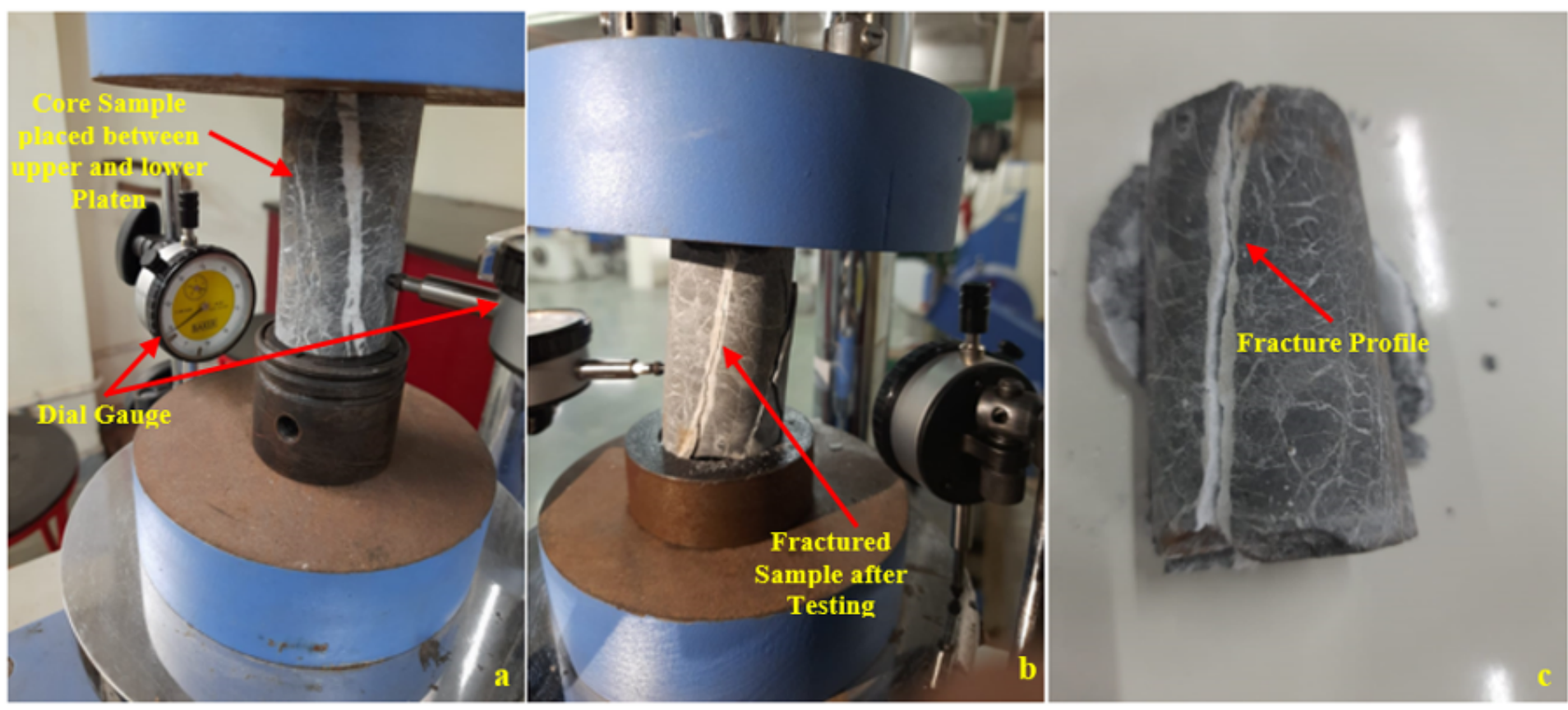


\section{Figure 9}

Compressive Strength Testing of Core Sample (a) Sample placed between upper and lower platen for testing (b) Fracture in core sample after testing (c) Fracture profile after the completion of testing
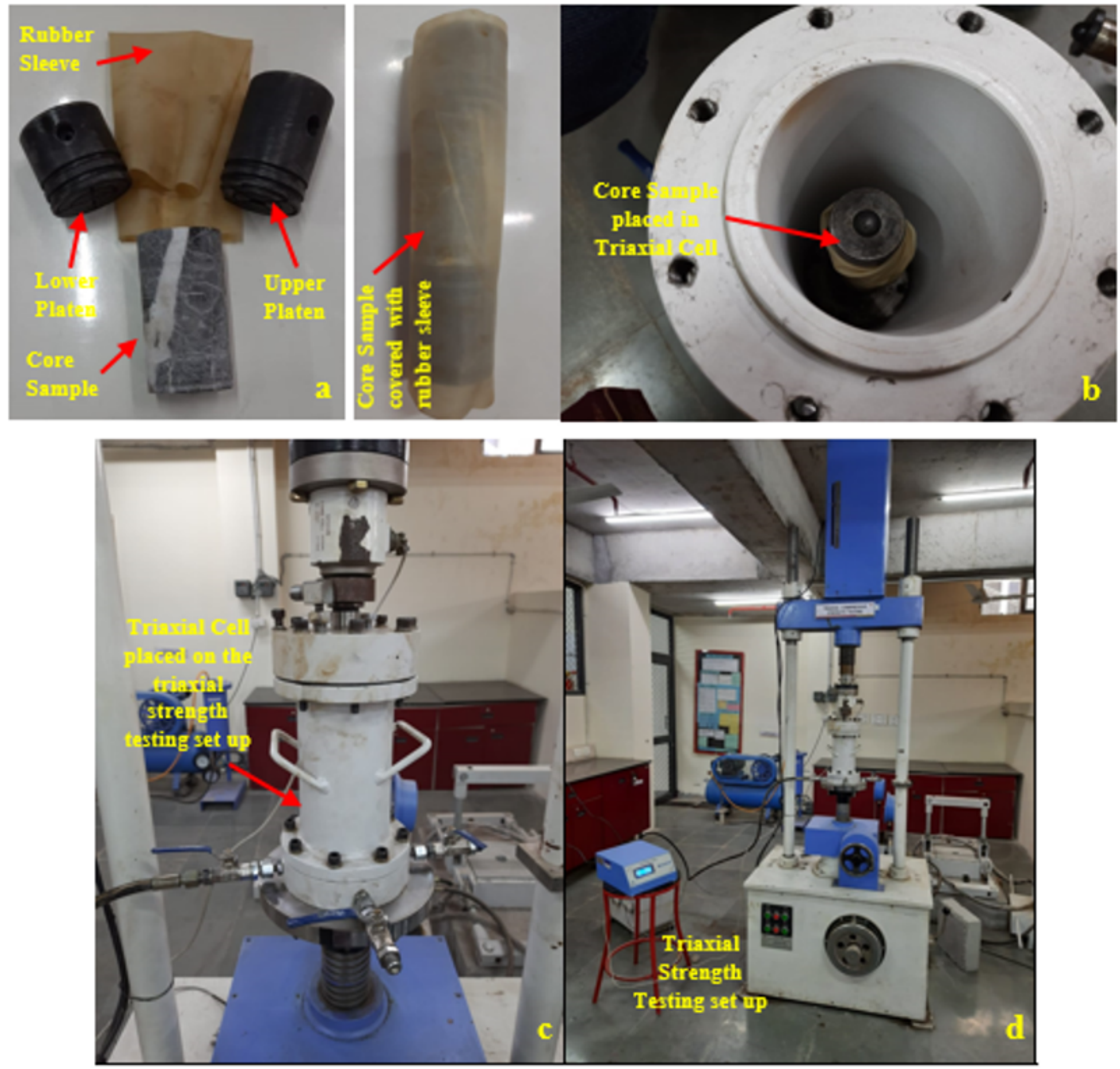

\section{Figure 10}

Triaxial Strength Testing of Core Sample (a) The sample with the connecting accessories (b) Sample placed in the triaxial cell (c) Triaxial cell placed on the testing frame (d) Triaxial strength testing set up 


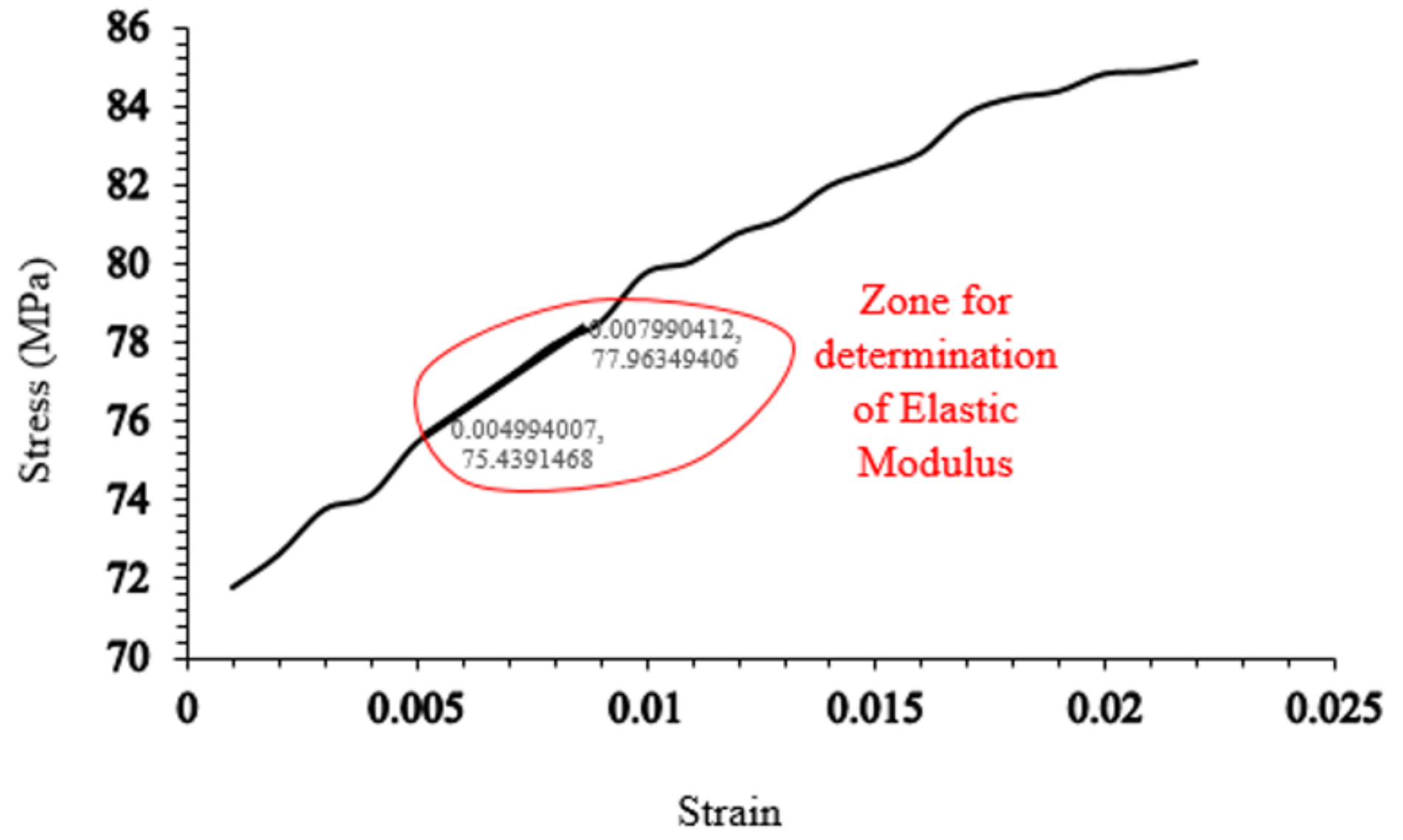

Figure 11

Stress-strain graph of core sample

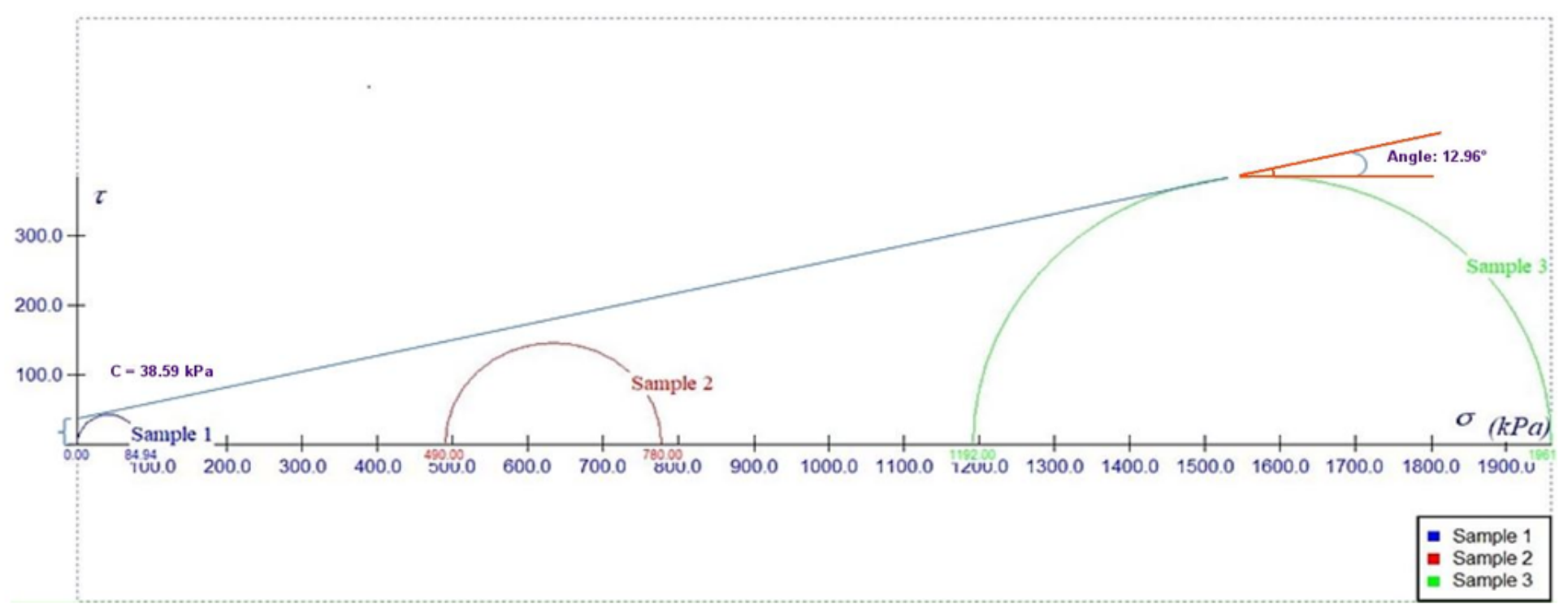

Figure 12

Mohr's Circle for determination of cohesive strength and angle of internal friction 


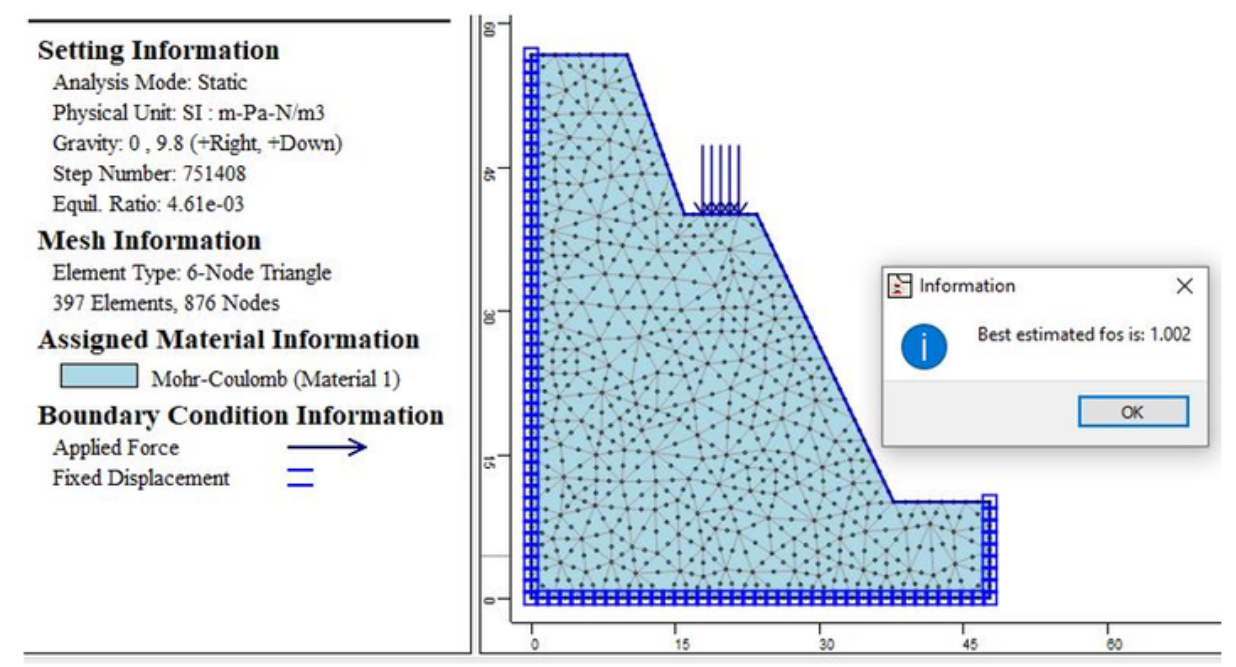

a.

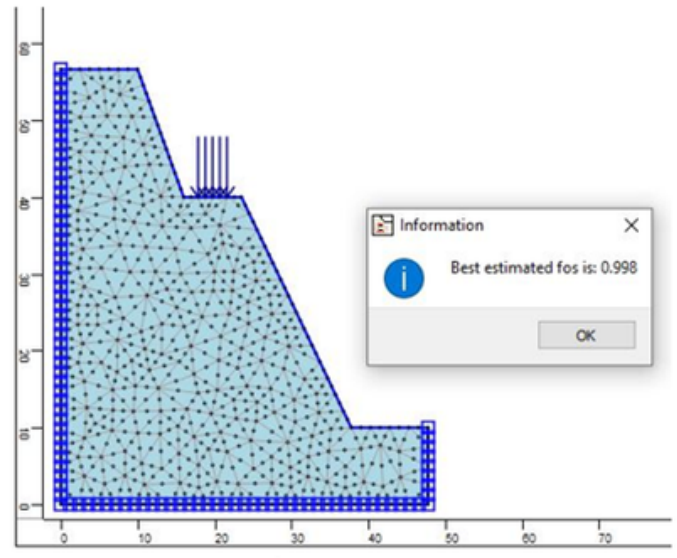

b.

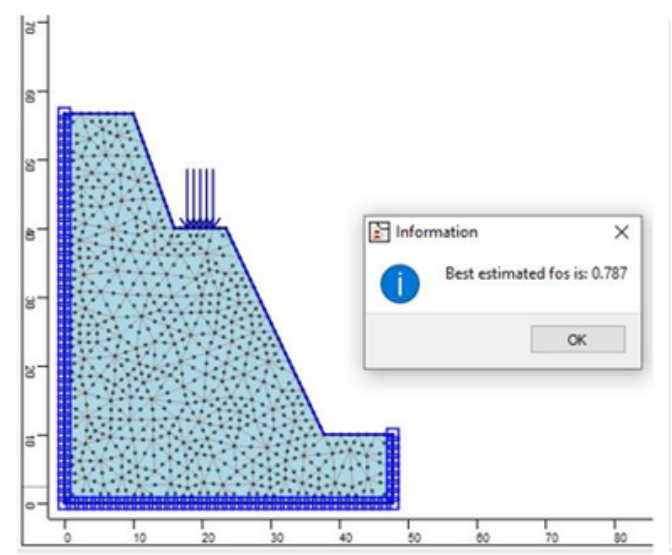

d.

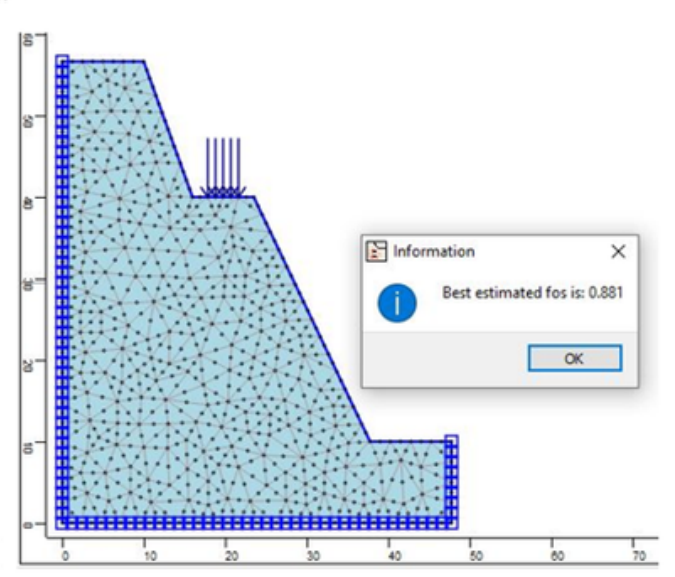

c.

\section{Figure 13}

Factor of safety at variable load (a) Load 100 kN (b) Load 500 kN (c) Load 1000 kN (d) Load 1500 kN (e) Load $2000 \mathrm{kN}$ 


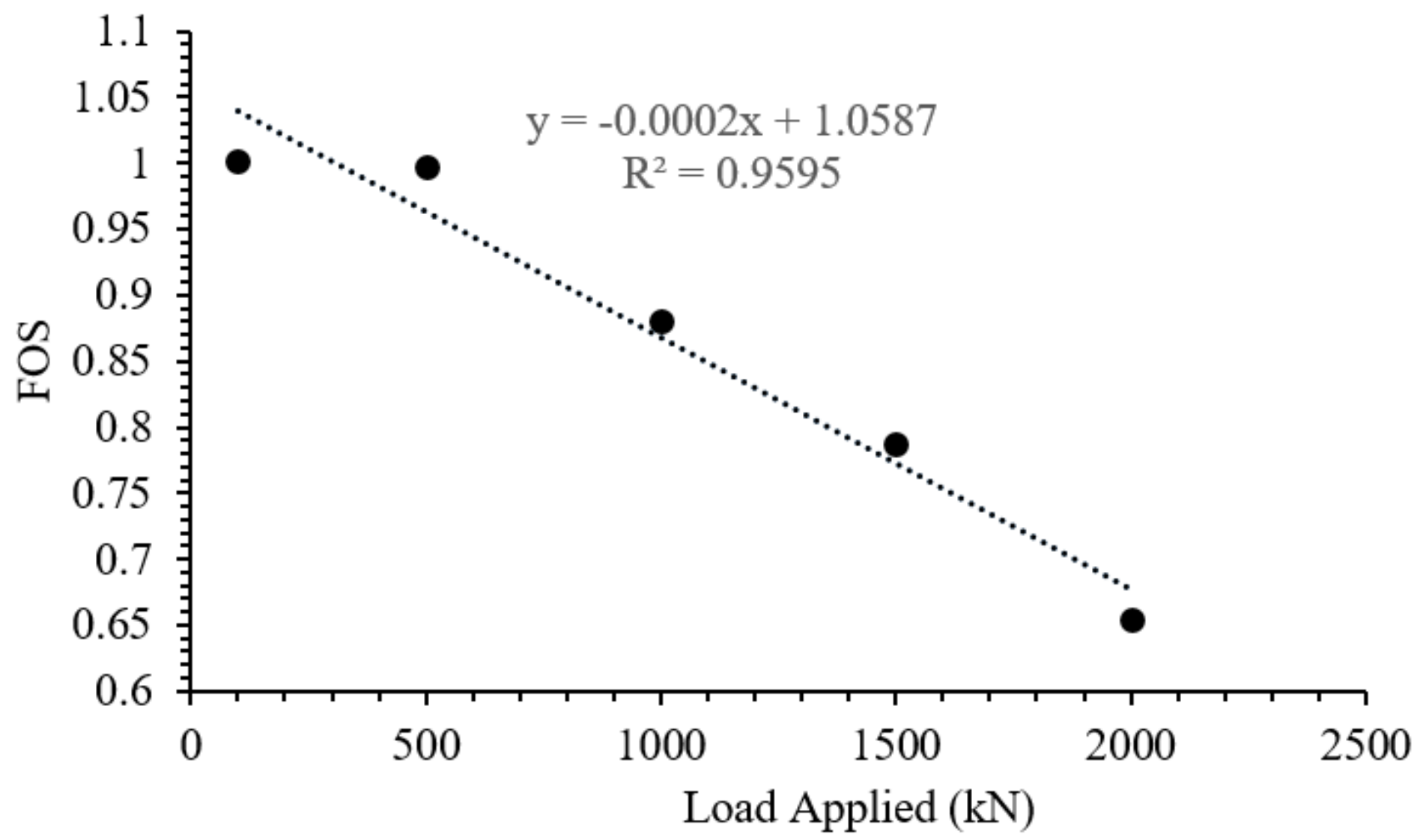

Figure 14

Variation of Factor of Safety (FOS) with load applied 


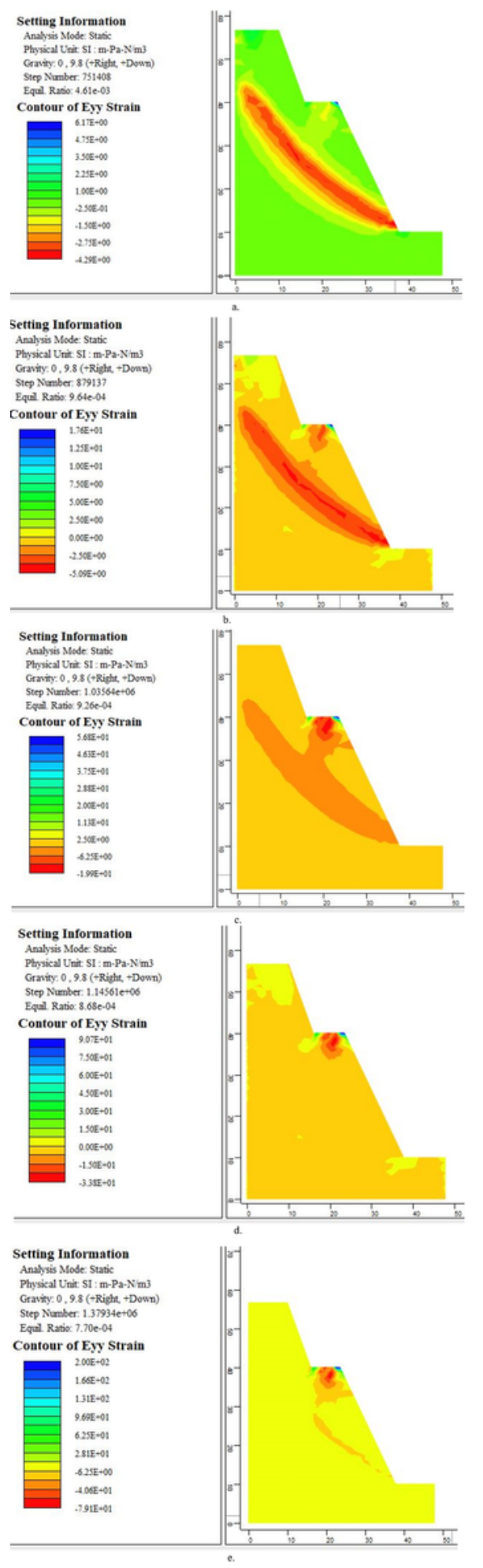

Figure 15

Strain developed in the structure at variable load (a) Load 100 kN (b) Load 500 kN (c) Load 1000 kN (d) Load 1500 kN (e) Load 2000 kN 